\title{
Policy Regarding Increased Control of Circulation or Trade of Dog Meat in Karanganyar Regency (Reviewed through the concept of Animal Welfare and The Rule of Adz-Dzariah Fiqh)
}

\author{
Nuria Siswi Enggarani \\ Universitas Muhammadiyah Surakarta \\ nse178@ums.ac.id \\ Wisnu Tri Nugroho \\ Universitas Muhammadiyah Surakarta \\ wisnutrinu@gmail.com
}

DOI: $10.23917 /$ jtl.v2i1.10934

\begin{abstract}
Submission
Track:

ABSTRACT

Received:

17 May 2020

Objective: This study aims to determine the implementation of policies regarding increasing supervision of the distribution or trade of dog meat in Karanganyar regency and to find out the policy review through the concept of animal welfare and adz-dzariah rules.
\end{abstract}

Final Revision:

Methodology: This research is a juridical-empirical method, with the type of research 04 July 2020 being analytic descriptive, and the data collection method used is library research and field research.

Finding: This research shows that the implementation of policies regarding the increase of supervision on the distribution or trade of dog meat in Karanganyar is

Available online: divided into the stages of pre-implementation, implementation, and post-

31 July 2020 implementation. The policy is also a step towards realizing the concept of Animal Welfare because this policy will stop the torture of dogs. In contrast, in the rule of adzdzari'ah fiqh, the implementation of the policy is to implement the sharia maqashid, which aims to protect Al-Kulliyah Al-Khamsah.

Corresponding

Author:

Application of the Study: The policy on increasing supervision of the distribution or

Nuria Siswi

nse178@ums.ac.id trade of dog meat is essentially to prevent the spread of zoonoses and stop the practice of violence against dogs. While this research is expected to provide an overview and information on the implementation of the policy.

Originality/Novelty: This research can be categorized differently from previous studies, where this research is more focused on the implementation of policies in Karanganyar which are then analyzed with the concept of Animal Welfare and the rule of adz-dzari'ah fiqh.

Keywords: Adz-Dzari'ah, Animal Welfare, Policy, Maqashid Syari’ah 


\section{INTRODUCTION}

Based on data in 2017 published by the Dog Meat Free Indonesia community, there are around 1,000,000 dogs that are killed every year to meet human food needs, whereas according to Law Number 18 Year 2012 Regarding Food, dog meat is not included in the category of food ingredients, because dog meat does not meet the food safety element, as referred to in the provisions of article 1 number 5 of the Food Law which states:

"Food Safety is a condition and effort needed to prevent food from possible biological, chemical and other contaminants that can disturb, harm and endanger human health and do not conflict with the religion, beliefs, and culture of the community so that it is safe for consumption "

In addition, in striving to fulfill the supply of dog meat for the community, the merchants do not hesitate to work through processes that are contrary to the law, namely through arrest, theft, and distribution which are not equipped with clear legal documents. ${ }^{1}$ Facts about the existence of violence and the high consumption of dogs have implications for the neglect of animal welfare and the lack of supervision of the control of zoonotic diseases carried by dogs.

Based on such conditions, the government through the Ministry of Agriculture Directorate General of Animal Husbandry and Animal Health issued Circular Letter Number 9874/SE/PK.420/F/09/2018 addressed to all Agencies that conduct animal husbandry and animal health affairs at the local government level to increase supervision of the distribution or trade of dog meat in the midst of society. The existence of this policy is a form of progress in working towards the achievement of the concept of animal welfare. Still, it is also seen as a step in working to ensure safe and healthy food for the community.

Although the start of this policy was approved by the good thinking of stakeholders about how animals need to be treated well and guaranteed their rights to live the issuance of the policy posed a problem, namely the assumption of some circles who considered the policy discriminatory and created unemployment because many people were dependent their income from dog meat business. Besides that, in practice, the implementation of the policy also experienced many developments, for example, in Karanganyar Regency, which developed into a policy prohibiting the circulation or trade of dog meat, where all forms of dog meat trade activities are not permitted.

\footnotetext{
1 Dog Meat Free Indonesia, Perdagangan Daging Anjing di Indonesia: Campaign Briefing,https://www.dogmeatfreeindonesia.org/images/PDF/DMFI Media Campaign Briefing IND.pdf,
} 
The policy regarding the prohibition on the distribution or trade of dog meat in Karanganyar was announced by the Regent aimed at preventing the spread of various diseases caused by consuming dog meat. Therefore his side would immediately close all food stalls selling dog-based dishes in Karanganyar. ${ }^{2}$ The expansion of the meaning of policies by the Karanganyar Regional Government is a concretization of the role of the regional government in realizing animal welfare as referred to in article 67 of the Law on animal husbandry and animal health which states:

"The implementation of animal welfare as referred to in Article 66 section (1) and section (2) shall be carried out by the Government and Regional Government together with the society."

In Karanganyar this policy has received several unfavorable reactions from some dog meat-based food traders, arguing that this policy will hamper the economic growth of citizens and open maximum access to unemployment and the absence of a clear law in the form of local regulations regarding the prohibition of meat trade or trade dogs in Karanganyar.

In connection with the problems surrounding the implementation of policies regarding the increase and supervision of the distribution or trade of dog meat in Karanganyar as stated above, to resolve this in Islam the existence of the Fiqhiyyah Rule has been recognized, The rule of fiqhiyyah is a general bond of some Islamic legal issues that can be used by laypeople and fuqahâ in finding solutions to legal problems that arise in the community in various themes of worship, muamalah, and contemporary Islamic legal issues. ${ }^{3}$

Based on the description described above, this research will specifically discuss the implementation of policies in the Karanganyar region, and then analyze whether the policy has realized the concept of animal welfare, which is free from thirst and hunger free from discomfort; free from pain, injury, and disease; free to express normal behavior; and free from fear and stress, ${ }^{4}$ and protection of maqashid shar'iah, namely guarding religion and beliefs, protecting souls, protecting offspring, protecting mind or intellect, and protecting property. And

${ }^{2}$ DetikNews, Kamis 20 Juni 2019, 07:47 WIB: Tentang Rencana Bupati Tutup Semua Warung Daging Anjing di Karanganyar, dalam https://news.detik.com/berita-jawa-tengah/d-4592964/tentang-rencana-bupatitutup-semua-warung-daging-anjing-di-karanganyar

${ }^{3}$ Hillal, Syamsul, Qawâ'Id Fiqhiyyah Furû'Iyyah Sebagai Sumber Hukum Islam, Jurnal Al-‘Adalah Vol. XI, No. 2 Juli 2013.

4 Office International des Epizooties. Introduction to the recommendation for animal welfare; terrestrial animal health code, http://web.oie.int/eng/normes/mcode/en_chapitre_1.7.1.pdf 
this research will provide a formulation of answers to overcome the problem of policy implementation in Karanganyar using Adz-Dzariah fiqhiyyah rules.

\section{RESEARCH METHOD}

The research method is a method of working to be able to understand the objects that are the target of the relevant science. The research method in determining it is considered important because there is a close relationship between the type of research with systematic and method and data analysis to achieve high validation values both the data collected and the final results of the study. ${ }^{5}$ The method of approach used in this research is the Juridical-Empirical approach, which means analyzing the problem by integrating legal materials (which are secondary data) with primary data obtained in the field, namely the implementation of policies in Karangnyar Regency. This research is descriptive-analytic, which is a method used to describe a condition that is happening, namely regarding the implementation of policies regarding increased supervision of circulation or trade in dog meat. The type of data used in this study is primary data that is data directly obtained from parties related to the object under study, which in this case is data in the form of interviews and observations in the field, data obtained from the Department of Commerce, Department of Fisheries and Animal Husbandry, Department of Health, and the Ministry of Religion in Karanganyar Regency, and the Animal Lover Community. Secondary Data is data obtained in the form of already made publications/reports. ${ }^{6}$ The data collection method used by the author is a method of library research and field research, namely by studying and understanding the laws and regulations, books, internet sites related to the object to be studied and searching data at the research location. While the data analysis is done qualitatively, that is the existing data made in words and or sentences.

\section{DISCUSSION}

Implementation of Policies Regarding Increased Control of Circulation or Trade in Dog Meat in Karanganyar Regency

The supervision of the distribution or trade of dog meat carried out in the Karanganyar area is a follow-up from the instructions of the Ministry of Agriculture of the Republic of

\footnotetext{
${ }^{5}$ Suratman \& Phlilips Dillah, 2013, Metode Penelitan Hukum, Bandung: CV.Alfabeta, hal. 44-45

${ }^{6}$ J.Supranto, 2003, Metode Penelitian hukum dan Statistik, Jakarta: PT. Rineka Cipta, Hal 2.
} 
Indonesia, precisely the Directorate General of Animal Husbandry and Animal Health which the policy substantiates an appeal to all regional agencies to take steps to supervise the circulation and trade of dog meat systematically in respective regions. The implementation of the policy regarding increased supervision of the distribution and trade of dog meat which later developed into a prohibition on the distribution or trade of dog meat in Karanganyar instructed by the Regent of Juliatmono in detail is motivated by the following considerations:

1) As a step to prevent the spread of rabies (zoonosis) to the public,

2) There is a consideration that dogs are not included as livestock so that their significant use as food cannot be justified,

3) Assuming the circulating dog meat comes from outside the karanganyar area which incidentally is not yet free from rabies so that it causes concern

4) The urge from the animal lovers community to Karanganyar Regional Government to immediately implement the policy ${ }^{7}$.

In connection with policies regarding increased supervision of the distribution or trade of dog meat carried out by Karanganyar Regional Government, it is not entirely in accordance with the instructions in circular number 9874 / SE / PK.420 / F / 09/2018. Still, it is adjusted to the culture of government and social needs existing community. The following can be described in the stages of the implementation of policies regarding increased supervision of the distribution or trade of dog meat by Karanganyar Regional Government:

\section{1) Pra-Implementation Policy}

\section{a) Public Discussion}

The discussion that was held was an open public discussion conducted by the Regent, Head of Service, and the Animal Lover community, which at that time was represented by the Dog Meat-Free Indonesia community on June 18, 2019. In this discussion, an agreement was reached that all forms of distribution or trade in dog meat in Karanganyar region are prohibited. ${ }^{8}$

\section{b) Policy Formulation}

Policy formulation is a series of activities in preparing, implementing, and controlling policies. This policy formulation is composed of 1) Agenda Formulation,

\footnotetext{
${ }^{7}$ Sutiyarmo, Dokter Hewan Dinas Perikanan dan Peternakan Kabupaten Karanganyar, Wawancara Pribadi, Karanganyar, Selasa, 14 Januari 2020, Pukul 13.05 WIB

${ }^{8} \mathrm{Ibid}$
} 
2) Policy Formulation, 3) Policy Adoption, 4) Policy Implementation, dan 5) Policy Assessment. 9

\section{2) Implementation of Policies}

\section{a) Data Collection and Field Survey}

Data collection and field surveys are needed to obtain valid data on the number of culinary businesses made from dog meat and its distribution in each district in Karanganyar region, find out the percentage of the area free from circulation or tradein dog meat, determine the amount of compensation for the profession that needs to be given and to find out challenges in implementing policies. After conducting data collection and field surveys and accurate data analysis, it is known that the number of culinary businesses made from dog meat reached 53 people, consisting of business operators operating in Karanganyar and Karanganyar Residents doing business outside the Karanganyar area.

\section{DATA OF CULINARY BUSINESSES MADE FROM DOG MEAT IN KARANGANYAR}

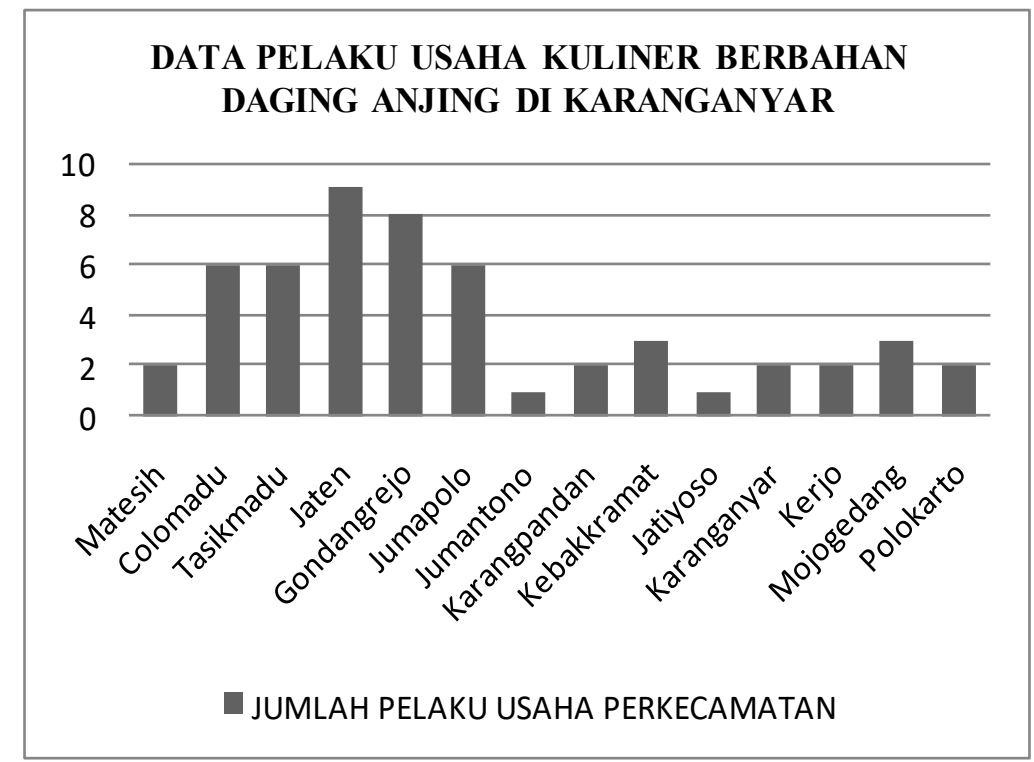

Picture 1. List of culinary businesses made from dog meat in Karanganyar

\footnotetext{
${ }^{9}$ Dunn, 2006, Analisis Kebijakan Publik, Yogyakarta Gadjah Mada University Press, Hal 24-28
} 
Thus obtained a percentage of the status of the area free of circulation or trade of dog meat in Karanganyar, as follows:

\section{- regardless of the circulation or trade of $\operatorname{dog}$ meat}

\section{- can not be separated from the circulation or trade in dog meat}

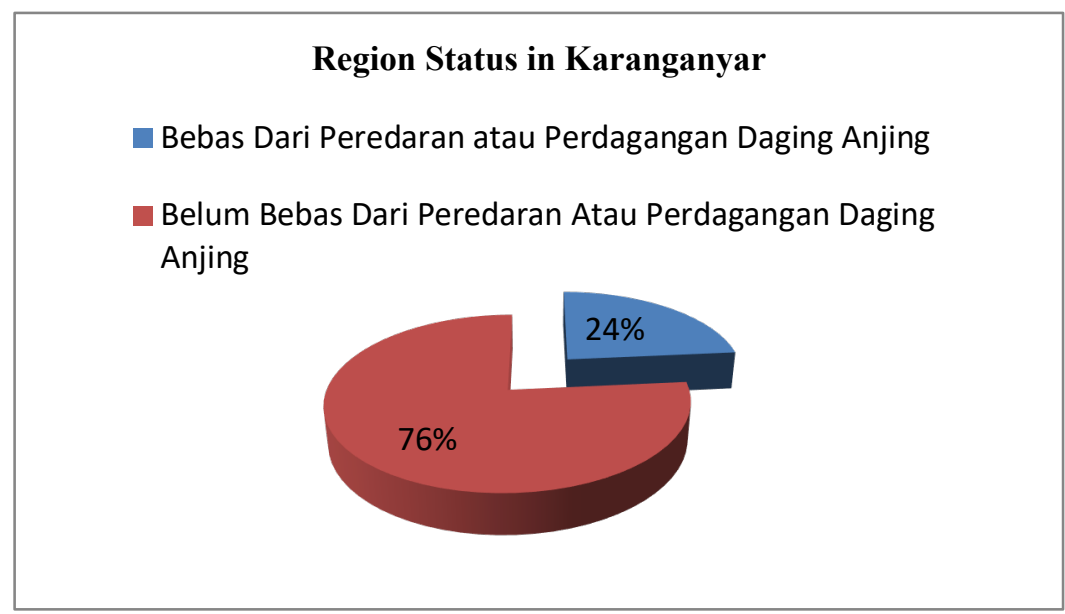

Picture 2. Data on a free area of circulation or trade of dog meat in Karanganyar

b) Socialization and Giving of the Changing Professional Transfer Compensation Funds

In the socialization, business actors are directed to switch to other businesses that are more feasible and close the culinary industry of dog meat forever (over the profession). In the change of the job, the government promised to provide compensation funds of Rp 5,000,000.00 (Five Million Rupiah) for each business actor willing to implement the policy. For business operators who do not agree (reject) this policy, the local government calls on them to close their businesses or not do business activities in Karanganyar (move) to those who continue to carry out activities that will be subject to sanctions. ${ }^{10}$ Based on the data, there are as many as 34 culinary entrepreneurs who receive compensation funds over the profession, and there are 19 people who reject the policy.

${ }^{10}$ Hartono, Dokter Hewan Dinas Perikanan dan Peternakan Kabupaten Karanganyar, Wawancara Pribadi, Karanganyar, Selasa, 14 Januari 2020, Pukul 13.05 WIB 


\section{c) Guidance}

Guidance for dog meat culinary business actors who accept the policy to switch professions is done by providing guidance to open businesses that are more feasible and useful, in addition, there is also assistance provided by Karanganyar local government for businesses that experience entrepreneurship. ${ }^{11}$ The change of profession that is directed by the regional government itself is often still correlated with previous work such as selling or other productive businesses.

\section{d) Socialization to The Community}

To socialize this policy among the people of Karanganyar regional government, they use the media platform, both online and in print, as well as using radio as an educational tool. ${ }^{12}$ The socialization carried out was also assisted by several animal lover communities or NGOs (Non-Governmental Organization) working in the protection of domestic animals through its media platform.

\section{3) Pasca- Implementation Policy}

\section{a. Monitoring dan Evaluation}

Regarding the monitoring of the implementation of this policy at the regional level by the Karanganyar Regional Government, it is still in the assessment and conceptualization stage by the Fisheries and Animal Husbandry Department. Still, at the lower levels (sub-districts and villages), there are several sub-districts and village heads who use their instruments to monitor the implementation of the policy. ${ }^{13}$

\section{Policy Regarding Increased Control of Circulation or Trade of Dog Meat in Karanganyar} Regency Viewed from the Concept of Animal Welfare and the Adz-Dzari'ah Fiqh Rule

- In terms of the Animal Welfare concept

A series of actions in the implementation of policies regarding increased supervision of the distribution or trade of dog meat that has evolved towards a ban by the Karanganyar District Government can be considered a new thing in realizing the concept of animal welfare, whereby the implementation of community policies will be encouraged to pay more attention to fulfilling

11 Yusuf Ihsanu Irham, Penyelenggara Syari'ah Kementerian Keagamaan Kabupaten Karanganyar, Wawancara Pribadi, Karanganyar, Jum'at, 10 Januari 2019, Pukul 09.15 WIB.

12 Sutiyarmo, Loc.It.

${ }^{13}$ Sutiyarmo, Loc.It. 
the right to health and animal welfare, given that prior to the implementation of the policy the practice of the distribution or trade of dog meat in Karanganyar often takes place without the existence of a strict supervisory and legal, regulatory mechanism from the relevant agencies, which implies opening access to increased criminal acts and brutal practices dog torture.

The implementation of policies in the Karanganyar area by the Government can be analyzed as an effort to realize the five principles of animal freedom, consisting of:
a. Free from hunger and thirst;
b. Free from pain, injury, and disease;
c. Free from inconvenience, torture, and abuse;
d. Free from fear and depression; and
e. Free to express their natural behavior. ${ }^{14}$

To see the relevance of the implementation of the policy with the concept of animal welfare can be seen in the following table:

\begin{tabular}{|c|c|c|c|}
\hline No & Principle & Provision & $\begin{array}{c}\text { Relevance in Policy in } \\
\text { Karanganyar }\end{array}$ \\
\hline 1 & $\begin{array}{l}\text { Freedom from } \\
\text { hunger and thirst }\end{array}$ & $\begin{array}{l}\text { - Do not obstruct animals in } \\
\text { their efforts to meet food } \\
\text { needs. }\end{array}$ & $\begin{array}{l}\text {-The prohibition on the } \\
\text { distribution or trade of dog meat } \\
\text { certainly has made dogs } \\
\text { unobstructed in meeting their food } \\
\text { needs, because with this policy } \\
\text { will stop the practice of dog } \\
\text { distribution that results in dogs } \\
\text { having to travel long distances } \\
\text { without eating and drinking. }\end{array}$ \\
\hline 2 & $\begin{array}{l}\text { Freedom from } \\
\text { discomfort }\end{array}$ & $\begin{array}{l}\text { - Animals are not treated } \\
\text { harshly, excessively, and } \\
\text { are not suitable for their } \\
\text { designation. }\end{array}$ & $\begin{array}{l}\text {-The Karanganyar Regional } \\
\text { Government stipulates that dog } \\
\text { meat is not food, so the designation } \\
\text { of dogs as one of the main food } \\
\text { sources is not justified. }\end{array}$ \\
\hline
\end{tabular}

${ }^{14}$ Office International des Epizooties, 2014, Terrestrial Animal Health Code Version 7, (07 Juli 2014) dalam http://web.oie.int/eng/normes/mcode/en_chapitre_1.7.1.pdf 


\begin{tabular}{|c|c|c|c|}
\hline & & $\begin{array}{l}\text { - Animals must be given } \\
\text { the freedom to make } \\
\text { themselves comfortable in } \\
\text { an environment where they } \\
\text { live while still protecting it } \\
\text { from the possibility that } \\
\text { this freedom is violated. }\end{array}$ & $\begin{array}{l}\text { - Implementation of the policy will } \\
\text { have implications for the decline in } \\
\text { dog theft practices that have been } \\
\text { happening so that the dogs can live } \\
\text { comfortably in the environment } \\
\text { where they live. }\end{array}$ \\
\hline 3 & $\begin{array}{l}\text { Freedom from } \\
\text { pain, injury, and } \\
\text { disease }\end{array}$ & $\begin{array}{l}\text {-Animals must obtain } \\
\text { guarantees where their } \\
\text { health is considered by the } \\
\text { social elements where they } \\
\text { live and grow. }\end{array}$ & $\begin{array}{l}\text {-The Karanganyar Regional } \\
\text { Government holds a dog brain } \\
\text { sample every year to test the } \\
\text { results of its health examination to } \\
\text { prevent HPR (animals carrying } \\
\text { rabies) }\end{array}$ \\
\hline \multirow[t]{2}{*}{4} & $\begin{array}{lr}\text { Freedom } & \text { to } \\
\text { express normal } \\
\text { behavior }\end{array}$ & $\begin{array}{l}\text { - Give freedom to animals } \\
\text { to interact socially and } \\
\text { mate. }\end{array}$ & \multirow[t]{2}{*}{$\begin{array}{l}\text { - In his consideration, Karanganyar } \\
\text { Regent saw the implementation of } \\
\text { this policy as giving the dog the } \\
\text { right to live according to their } \\
\text { essential nature. }\end{array}$} \\
\hline & & $\begin{array}{l}\text {-Allows animals to act } \\
\text { according to their instincts } \\
\text { without excessive human } \\
\text { restraints. }\end{array}$ & \\
\hline 5 & $\begin{array}{l}\text { Freedom from } \\
\text { fear and distress }\end{array}$ & $\begin{array}{l}\text { - Ensure that the conditions } \\
\text { and treatment that pets } \\
\text { receive are free from } \\
\text { everything that causes fear } \\
\text { and stress, such as conflicts } \\
\text { with other species and } \\
\text { interference from predators } \\
\text { and human activity. }\end{array}$ & $\begin{array}{l}\text {-Karanganyar Regional } \\
\text { Government prohibits the practice } \\
\text { of catching and the practice of } \\
\text { violence against dogs. }\end{array}$ \\
\hline
\end{tabular}


Table 1. The relevance of policy implementation to the concept of animal welfare

\section{- Reviewed From the Rule of Adz-Dzariah Fiqh}

The policy on increasing supervision of the distribution or trade of dog meat is a step that must be presented to reduce the spread of the phenomenon of people consuming dog meat, which will damage the existing creed, because after all dogs are unclean animals for consumption are also very dangerous for health and the security of mankind, so that the policy is directly or indirectly relevant in the effort to protect al-kulliyah al-khamsah which is the purpose of the existence of maqashid shari'ah, as explained in the following table: :

\begin{tabular}{|c|c|c|}
\hline No & Al-Kulliyah Al-Khamsah & Descriptions \\
\hline 1 & $\begin{array}{l}\text { Maintaining Religion and } \\
\text { Belief (hifzud-din) }\end{array}$ & $\begin{array}{l}\text { As we know that dogs in Islam are not included as food, } \\
\text { because they contain substances that are detrimental to } \\
\text { the body, because in his word Allah commands humans } \\
\text { to eat and drink from halal and good things that come } \\
\text { from the earth (Q.S. Al-Baqarah:168), in this way a ban } \\
\text { on the distribution or trade of dog meat can be interpreted } \\
\text { as an effort to preserve the faith in religion. }\end{array}$ \\
\hline 2 & $\begin{array}{l}\text { Keeping the soul (hifzun- } \\
n a f s \text { ) }\end{array}$ & $\begin{array}{l}\text { It is known that in dog meat, there is a risk of zoonotic } \\
\text { diseases that can be passed down to humans, such as } \\
\text { Rabies, Trichinosis, Bacteria e-Coli, and Salmonella, } \\
\text { which endanger the welfare of human life. So that with } \\
\text { the policy regarding increased supervision of the } \\
\text { distribution or trade of dog meat, the safety, and health of } \\
\text { citizens will be guaranteed through the implementation } \\
\text { of monitoring in the policy. }\end{array}$ \\
\hline 3 & $\begin{array}{l}\text { Look after offspring } \\
(\text { hifžun-nasl) }\end{array}$ & $\begin{array}{l}\text { Implementation of the policy can protect offspring from } \\
\text { the consumption of dog meat because the consumption of } \\
\text { dog meat that does not have a good impact on human } \\
\text { health can certainly endanger the survival of humanity. }\end{array}$ \\
\hline 4 & $\begin{array}{l}\text { Maintain mind or } \\
\text { intellectual (hifẓul-'aql) }\end{array}$ & $\begin{array}{l}\text { Violence against dogs is not something that comes from } \\
\text { the thoughts and conscience of healthy humans, so the } \\
\text { various cruel actions that occur in dogs to be used as food }\end{array}$ \\
\hline
\end{tabular}




\begin{tabular}{|c|l|l|}
\hline & & $\begin{array}{l}\text { is the wrong action. Thus, this policy will keep human } \\
\text { reason in line with the good. }\end{array}$ \\
\hline 5 & $\begin{array}{l}\text { Guarding the treasure } \\
(\text { hifzul-mal }) .\end{array}$ & $\begin{array}{l}\text { As known in seeking fulfillment of the needs of the } \\
\text { supplier, dog meat is not infrequently committing } \\
\text { criminal acts in the form of dog theft, which is certainly } \\
\text { not by the existence of the sharia maqashid, so to reduce } \\
\text { this trend this policy is very appropriate. }\end{array}$ \\
\hline
\end{tabular}

Table 2. The relevance of the implementation of policies with maqashid sharia

The implementation of increased supervision of the distribution or trade of dogs in Karanganyar cannot be categorized as being carried out to the fullest. This is based on various facts that explain the persistence of several problems regarding the implementation of the policy. This problem basically arises because the implementation of the policy is considered too hasty to be carried out without any more in-depth study, so to solve the problem, it can use Adz-Dzariah Fiqh rules to study and construct a solution to the policy implementation.

Following is the construction of problem-solving in implementing policy implementation in Karanganyar based on the Adz-Dzari'ah fiqh rules:

\begin{tabular}{|c|c|c|}
\hline $\begin{array}{c}\text { The Rules of Sad } \\
\text { Adz-Dzari'ah } \\
\text { Fiqh }\end{array}$ & Action & Purposes \\
\hline $\begin{array}{l}\text { A preventive } \\
\text { method in order to } \\
\text { safeguard bad } \\
\text { possibilities and to } \\
\text { prevent negative } \\
\text { impacts from } \\
\text { happening, this is } \\
\text { not meant as a }\end{array}$ & Field Supervision & $\begin{array}{l}\text { With the supervision in the field by the Office } \\
\text { and the relevant regional government } \\
\text { apparatus, it will be able to reduce the practice } \\
\text { of consuming dog meat in the community. } \\
\text { Also, with the supervision, it is expected that } \\
\text { the implementation of the policy can be } \\
\text { carried out optimally so that there are no } \\
\text { traders who violate the policy. }\end{array}$ \\
\hline $\begin{array}{l}\text { restraining effort, } \\
\text { but as a means to } \\
\text { achieve legal } \\
\text { objectives, namely } \\
\text { to realize benefit }\end{array}$ & $\begin{array}{c}\text { Do not issue } \\
\text { Veterinary } \\
\text { Certificates (Animal } \\
\text { Product Health } \\
\text { Certificate / }\end{array}$ & $\begin{array}{l}\text { To avoid the abuse of the health status of } \\
\text { animal product safety because dogs are not } \\
\text { food and do not meet the element of food } \\
\text { safety. }\end{array}$ \\
\hline
\end{tabular}




\begin{tabular}{|c|c|c|}
\hline \multirow[t]{4}{*}{$\begin{array}{ll}\text { and } & \text { avoid } \\
\text { damage. }{ }^{15} & \end{array}$} & $\begin{array}{c}\text { SKKPH) } \\
\text { specifically for dog } \\
\text { meat. }\end{array}$ & \\
\hline & $\begin{array}{l}\text { Monitoring dan } \\
\text { Evaluation }\end{array}$ & $\begin{array}{l}\text { The existence of monitoring and evaluation } \\
\text { can be used as a means to improve the } \\
\text { implementation of the policy going forward, } \\
\text { monitoring and evaluation need to be carried } \\
\text { out as a way to prevent the occurrence of } \\
\text { misappropriation of compensation funds for } \\
\text { businesses that have been provided by the } \\
\text { government and see the extent to which } \\
\text { community businesses develop. }\end{array}$ \\
\hline & $\begin{array}{c}\text { Issuance of } \\
\text { Karanganyar } \\
\text { Regional Regulation } \\
\text { Regarding the } \\
\text { Prohibition of } \\
\text { Circulation or Trade } \\
\text { of dog meat }\end{array}$ & $\begin{array}{l}\text { With the issuance of more specific regional } \\
\text { regulations governing Karanganyar } \\
\text { circulation or trade, it will provide legal } \\
\text { certainty regarding the implementation of the } \\
\text { policy and its sustainability, in addition to } \\
\text { that, the issuance of a Regional Regulation by } \\
\text { the Karanganyar District Government will } \\
\text { reinforce and clarify existing regulations } \\
\text { regarding the supervision of the health of } \\
\text { animal food as outlined in Karanganyar } \\
\text { Regent's Regulation Number } 74 \text { Year } 2019\end{array}$ \\
\hline & $\begin{array}{c}\text { Application of } \\
\text { Sanctions for Sellers } \\
\text { and Buyers of Dog } \\
\text { Meat }\end{array}$ & $\begin{array}{l}\text { To reinforce the commitment of the } \\
\text { Karanganyar Regional Government to stop } \\
\text { the practice of trafficking or trading dog meat } \\
\text { in the middle of the community, so that the } \\
\text { existence of these sanctions will provide a }\end{array}$ \\
\hline
\end{tabular}

\footnotetext{
${ }^{15}$ Nurdhin Baroroh, 2017, Metamorfosis “Illat Hukum” Dalam Sad Dan Fath Adz-Dzariah (Sebuah Kajian Perbandingan). Jurnal Il-mazahib, vol 5,No 2
} 


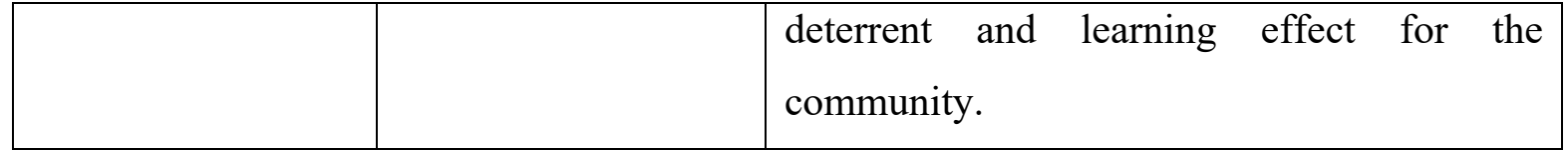

Table 3. Construction of Problem Solving implementation of policies based on the principles of fiqh Sad Adz-Dzari'ah

\begin{tabular}{|c|c|c|}
\hline $\begin{array}{l}\text { The Rules of Fath } \\
\text { Adz-Dzariah Fiqh }\end{array}$ & Action & oses \\
\hline $\begin{array}{l}\text { A method of } \\
\text { outcome that } \\
\text { means/means } \\
\text { means, tools, } \\
\text { and/or referees } \\
\text { must be raised and }\end{array}$ & $\begin{array}{l}\text { Continuous } \\
\text { Coaching }\end{array}$ & $\begin{array}{l}\text { As is known, the implementation of policies } \\
\text { in Karanganyar has not been accompanied by } \\
\text { ongoing training, so business operators who } \\
\text { switch professions require time for great } \\
\text { adaptations and difficulties in running new } \\
\text { businesses. }\end{array}$ \\
\hline $\begin{array}{l}\text { used if the results of } \\
\text { an act that uses the } \\
\text { facilities, tools } \\
\text { and/or referees } \\
\text { produce benefits } \\
\text { and goodness. }{ }^{16}\end{array}$ & $\begin{array}{l}\text { Establish } \\
\text { cooperation with } \\
\text { NGOs and the } \\
\text { Animal Lover } \\
\text { Community on an } \\
\text { ongoing basis }\end{array}$ & $\begin{array}{l}\text { The involvement of NGOs and Animal Lover } \\
\text { Communities in implementing this policy is } \\
\text { something that must be present, because the } \\
\text { role of both is very significant in overseeing } \\
\text { the effectiveness of the implementation of the } \\
\text { policy in the community, even based on } \\
\text { interviews with RSAT Palangkaraya stating } \\
\text { NGOs and communities will be willing to } \\
\text { help the government to oversee the policy } \\
\text { systematically and responsibly. }\end{array}$ \\
\hline & $\begin{array}{l}\text { Strengthen the role } \\
\text { of the parties in } \\
\text { policy }\end{array}$ & $\begin{array}{l}\text { Strengthening the role of the parties is } \\
\text { something that needs to be presented and } \\
\text { implemented given the magnitude of the } \\
\text { objectives to be addressed, the process of } \\
\text { implementing the policy also needs a good } \\
\text { working mechanism among policy makers }\end{array}$ \\
\hline
\end{tabular}

Table 4. Construction of Problem Solving of the implementation of policies based on the principles of fiqh Fath Adz-Dzari'ah

\footnotetext{
${ }^{16}$ Wahbah Zauhaili, Al-Wajiz fi Usul al-Fiqh. Beirut: Dar al-Fikri. 1999, Hal 108.
} 


\section{CONCLUSION}

The implementation of the policy regarding increased supervision of the distribution and trade of dog meat which later developed into a prohibition on the distribution or trade of dog meat in Karanganyar has fulfilled the instructions in circular number 9874 / SE / PK.420 / F / 09/2018 but with adjustments to culture governance and social needs of the community. Implementation of the policy can be considered as a new breath in the step of realizing the concept of animal welfare (Animal Welfare) because the existence of this policy will stop the torture of dogs. It is reviewed from the rule of fiqh adz-dzari'ah that the implementation of the policy is to implement the sharia maqashid which aims to protect Al-Kulliyah Al-Khamsah.

Based on the above rules, a solution is formulated to solve the problems in the implementation of the policy in Karanganyar which is grouped into 2, namely:

1) Based on the rules of fiqh sad adz-dzariah, such as: Supervision in the Field, Not issuing Veterinary Certificates (Animal Product Health Certificate / SKKPH) specifically for dog meat, tightening supervision of traffic distribution or trade in dog meat, and Monitoring and Evaluation.

2) Based on the rules of fiqh fath adz-dzari'ah, such as: Sustainable Development, Establishing cooperation with NGOs (Non Governmental Organization), and Animal Lover Communities on an ongoing basis, and strengthening the role of the parties in policy. 


\section{REFERENCES}

Dunn, (2006), Analisis Kebijakan Publik (Public Policy Analysis), Yogyakarta : Gadjah Mada University Press.

Hillal, Syamsul, Qawâ'Id Fiqhiyyah Furû'Iyyah Sebagai Sumber Hukum Islam, Jurnal Al'Adalah Vol. XI, No. 2 Juli 2013. (Qawâ'Id Fiqhiyyah Furû'Iyyah as a Source of Islamic Law, Journal Is Vol. XI, No. July 2, 2013)

J.Supranto, (2003), Metode Penelitian hukum dan Statistik (Legal and Statistical Research Methods ), Jakarta: PT. Rineka Cipta.

Nurdhin Baroroh, 2017, Metamorfosis "Illat Hukum” Dalam Sad Dan Fath Adz-Dzariah (Sebuah Kajian Perbandingan) (Metamorphosis of "Illat Law" in Sad and Fath AdzDzariah (A Comparative Study)), Jurnal Il-mazahib, vol 5, No 2

Suratman \& Phlilips Dillah, (2013), Metode Penelitan Hukum (Legal Research Methods), Bandung: CV.Alfabeta.

Wahbah Zauhaili, (1999), Al-Wajiz fi Usul al-Fiqh. Beirut: Dar al-Fikri.

Interview:

Hartono, Dokter Hewan Dinas Perikanan dan Peternakan Kabupaten Karanganyar, Wawancara Pribadi, Karanganyar, Selasa, 14 Januari 2020, Pukul 13.05 WIB (Veterinarian of Karanganyar Regency Fisheries and Animal Husbandry Department, Personal Interview, Karanganyar, Tuesday, January 14, 2020, at 13.05 WIB)

Sutiyarmo, Dokter Hewan Dinas Perikanan dan Peternakan Kabupaten Karanganyar, Wawancara Pribadi, Karanganyar, Selasa, 14 Januari 2020, Pukul 13.05 WIB (Veterinarian of Karanganyar Regency Fisheries and Animal Husbandry Department, Personal Interview, Karanganyar, Tuesday, January 14, 2020, at 13.05 WIB)

Yusuf Ihsanu Irham, Penyelenggara Syari'ah Kementerian Keagamaan Kabupaten Karanganyar, Wawancara Pribadi, Karanganyar, Jum'at, 10 Januari 2019, Pukul 09.15 WIB. (Sharia organizer of Karanganyar Regency Ministry of Religion Affairs, Personal Interview, Karanganyar, Friday, January 10, 2019, 09.15 WIB.)

Website :

DetikNews, Kamis 20 Juni 2019, 07:47 WIB: Tentang Rencana Bupati Tutup Semua Warung Daging Anjing di Karanganyar, dalam https://news.detik.com/berita-jawa-tengah/d4592964/tentang-rencana-bupati-tutup-semua-warung-daging-anjing-di-karanganyar, di unduh Senin 07 Oktober 2019, 06.05 WIB (Thursday, June 20, 2019, 07:47 WIB About the Regent's Plan to Close All Dog Meat Stalls in Karanganyar, in https://news.detik.com/berita-jawa-tengah/d-4592964/tentang-rencana-bupati-tutupsemua-warung-daging-anjing-di-karanganyar, downloaded Monday, October 7, 2019, 06.05 WIB)

Dog Meat Free Indonesia, Perdagangan Daging Anjing di Indonesia: Campaign Briefing,https://www.dogmeatfreeindonesia.org/images/PDF/DMFI_Media Campaign Briefing_IND.pdf, diunduh pada 07 Oktober 2019, pukul 05.17 WIB

(Dog Meat Trade in Indonesia: Campaign Briefing, https: //www.dogmeatfreeindonesia.org/images/PDF/DMFI_Media_Campaign_Briefing_IND. pdf, downloaded on 07 October 2019, at 5:17 WIB WIB)

Office International des Epizooties. Introduction to the recommendation for animal welfare; terrestrial animal health code, http://web.oie.int/eng/normes/ 
mcode/en_chapitre_1.7.1.pdf, diakses pada 18 November 2019, Pukul 11.06 WIB (Introduction to the recommendation for animal welfare; terrestrial animal health code, http://web.oie.int/eng/normes/ mcode / en_chapitre_1.7.1.pdf, accessed on 18 November 2019, 11.06 WIB)

Office International des Epizooties, 2014, Terrestrial Animal Health Code Version 7, (07 Juli 2014) dalam http://web.oie.int/eng/normes/ mcode/en_chapitre_1.7.1.pdf, diunduh Jum'at 13 Desember 2019, Pukul 11.06 WIB (Terrestrial Animal Health Code Version 7, (July 7, 2014) in http://web.oie.int/eng/normes/ mcode / en_chapitre_1.7.1.pdf, downloaded Friday 13 December 2019, 11.06 WIB) 